\title{
Millitating Factors On The Efficient Management Of Students' Record Among Registry Staff In Academic Institutions (A Case Study Of Babcock University)
}

\author{
Goodluck Okwudiri Allison \\ Laz-Otti Memorial Library \\ Babcock University, Ilishan-Remo, Ogun State \\ Chima Evans Otuza PhD \\ Department of Information Resources Management \\ Babcock University, Ilishan-Remo
}

\begin{abstract}
Management of students' records is crucial to all universities as they rely on their information for future decision making and university growth; unfortunately in Nigerian universities today, it seems little or no attention is given to students' record management especially in registry which is the bedrock of students' records. This study examined the factors affecting efficient management of students' record among record management personnel in Babcock University. A survey design was employed for the study. The population consisted of all the registry staff of Babcock University with a total number of 102 staff who served as the sample for the study. A self-structured questionnaire titled (FAEMSR) with the Likert four point scale in order of strongly Agree $=4$, Agree $=3$, disagree $=2$, strongly Disagree $=1$, and two point scales of yes or No and Attended or Not Attended were used to gather data validated with overall Cronbach alpha reliability coefficient of 0.97 ; all the staff participated in the study and subsequently, the study was analyzed using descriptive statistics. Findings certified that there is little number of staff in the registry with records management qualification or with related courses. It also show negative factors associated with efficient management of students' records in Babcock University as: negative attitude of staff, badly implemented record management system, insecurity of records, use of paper convention, lack of training, manual operation, inadequate computer terminal and resources to ineffective retrieving, retention and disposition schedule, as well as lack of policy and filing procedure manual. The study concluded that a major factor that militate against efficient management of students' record rests on the fact that high number of personnel in the registry are yet to have requisite qualifications in records management to work in registry. Therefore, the study recommended that all registry staff should have basic qualifications in records management or related fields, and a regular training be carried out on a semester basis for all the personnel in the department.
\end{abstract}

KEY WORDS: Record, records management, Effective Management, students' Records, Registry, personnel

Word Count: 315

\section{INTRODUCTION}

Records are evidences of business transactions between one person and another or with group of persons. Records are "assets" as single copy of it mismanaged can destroy both an individual and organization (Oyebo, 2016). The term records, as defined by Read and Ginn (2011), "are stored information, regard less of media or characteristics, made or received by an organization that is evidence of its operations and has value requiring its retention for specific 
period of time". Students' records are critical in achieving university's goals and objectives. The role of records management in education institutions cannot be over-emphasized. It is difficult to attain development without records.

Government Records Service (2011) sees records as valuable assets of organizations. Good records management not only helps protect records but also enhances organizations' operational efficiency. Record management especially in university set-up brings to bare the longevity of that school; in that the continuity of the school solely depends on availability of useful records and past activities. In a university environment also, it is absolutely impossible to keep every information in the brain owing to the volume of available information, and as such, records must be kept.

Record keeping/management is so important that it predated the existence of man. For instance, in the holy book Genesis 1 and 2 God kept a chronological and historical record of all his work during creation from day one when he created heaven and earth to the seventh day when he rested from his works which he made. In the same vein, universities keep chronological records that keep the institution alive in terms of academic record. Fadokun (2004) and Tower (2004) who states that adequate security, storage facilities and funds serves as necessities for good record management. Then Nwaomah, (2015) asserts that in educational institutions such as a university, academic/educational records refers to information or data relating to students both in paper and electronic formats that provides evidence of and information about the actions or events that happened. These events are created through the processes of admission, matriculation, examination and convocation to mention but a few. Without proper management of these records, the future of the university will be dimmed.

According to Research Clue (2014), record management is the practice of maintaining the records of an organization from the time they are created up to their eventual disposal: this may include classifying, storing, securing and destruction (or in some cases, archival preparation) of records. Records management is primarily concerned with the evidence of an organizations activity and is usually applied according to the value of the records rather than their physical format. Furthermore, Omoha (2013) adds, the purpose of record management is to ensure that accurate and proper records of students' achievement and growth, information on school activities and matters that will promote efficiency and effectiveness of the school system are kept, among others. Adequate records management programme co-ordinates and protects institutions' records, sharpens the effectiveness of records as a management memory which controls the times, equipment and space allocated to records and helps to simplify intraorganizational and communication problems. The management of students' records in universities, like in any other organization, is a cyclic process involving categorically registry staff.

Nwaomah (2015) citing Popoola (2000), Atulomah (2011), and (JISC IfoNet, 2007) indicated that information and records management are foundational to business activity. The absence of information can cripple the planning and decision making process of management. This fact is very applicable to a university records management concerning its student records. From a broad perspective, the creation and maintenance of records relating to the students of an institution are essential to managing the relationship between the institution and the student; providing support and other services and facilities to the students; controlling the students' academic progress and measuring their achievement, both at the institution and subsequently; providing support to the students after they leave the institution. With this development, one can ask, of what importance is students' records management to the university and its community? According to Ifedili and Agbaire (2011) add that: 
- Educational researchers find relevance in educational/academic records for their researches towards contributing to knowledge

- Educational regulatory bodies rely so much on education/academic records to evaluate the status of governance of an institution and academic quality of schools. As well as

- School administrators who rely on records to evaluate students' performance and reward same.

In addition, Further, Anho (2006), citing Anderson and Dyke (1992); Olagboye (2004), states that the significance of student records include:

$\checkmark$ Provision of data for planning and decision making by school heads, ministry of education and other related authorities;

$\checkmark$ Facilitation of continuity in the administration of a school, research activities that will promote efficiency and effectiveness; and

$\checkmark$ Ensuring that accurate and proper records of student's achievement and growth during his/her school days are kept and to report same to parents/guardians, employers, other institutions for students admission or job placement.

Record management occupies a strategic position in the efficient and effective management of the university systems as Blink (2015) stated, the goals of record management include ensuring that administrative records are appropriately managed, preserved, secured, and can be retrieved as needed. It is important that registry staff saddled with much responsibility of minding students records get familiar with the legal and ethical requirement for record keeping in their specific professional context and jurisdiction. Generally, record management must be guided by some level of confidentiality, proper maintenance, security, and preservation of the content and context etc (Uwaifo, 2004, Akporhonor and Iwhiwhu, 2007).

However, irrespective of the important role played by records management as indicated above, there is still a consensus amongst researchers that many organizations pay little attention to the management of records and handle recorded information carelessly without realizing that records constitute a major resource compared to finance, people, money and equipment (Mnjama, 2004; Ngulube, 2004; Chinyemba \& Ngulube, 2005; Egwunyenga, 2009 \&Walala, 2010). Fabunmi \& Isah (n.d) assert that it has become a recurrent issue for records to be irretrievable when required specially in Nigerian tertiary institutions as noted by Nwaomah, (2015). More of these factors include: insufficient skilled and experienced record management personnel, low priority of record management in scheme of things, lack of record manual and filing guidelines which leads to loss of vital information, inadequate computer terminals /internet, difficulty in record retrieval, and improper formulation of policies. Others are inaccurate, unavailable/incomplete and dishonest records, negative attitude of staff towards record keeping, inadequate resource, lack of record retention and deposition, lack of cohesive continuity in the affairs of the university, and misplaced records.

\section{STATEMENT OF PROBLEM}

Management of student record is viewed as very important in universities as it enables storage/preservation and retrieval of vital information needed for university growth. But unfortunately, it seems that in Nigerian universities today, little or no attention is given to record management especially the registry which holds the life history of students' records (admission, matriculation, registration, examination, and graduation, among others). Instead, handful of setbacks are recorded in terms of improper security of records, inadequate resource, incompetent trained personnel, hiring and placing of people based on who they know, use of manual system in recording and storing of information and negative attitude of staff towards record keeping. Considering the above no doubt, students' records are in 
jeopardy and thus this paper to identify the factors affecting efficient management of students' record among record management personnel (case study of Babcock University)

\section{OBJECTIVE OF THE STUDY}

The general objective of the study is to determine the factors affecting efficient management of students' records among record management personnel in Babcock University, Ilisan Remo, Nigeria. The specific objectives of the study include:

1. To find out if students records are effectively managed in terms of time, efficiency, and up datedness

2. To find out the efficiency of the personnel in Babcock University registry

3. To find out the problems encountered in the process of having efficient management of students' records in Babcock University registry

4. To proffer solutions on how to improve the management of students' records in Babcock University registry.

5. To identify the programmes registry staff are exposed to on records management that enhances the effective management of students records

\section{RESEARCH QUESTIONS}

Based on the above indications, the following questions are raised

1. Is students' records effectively managed in terms of time, efficiency and up datedness in Babcock University registry?

2. How efficient is the personnel in Babcock University registry in managing of students' records?

3. What are the problems associated with efficient management of students' records in Babcock University Registry?

4. What ways/options can be used to improve management of students' records in Babcock university registry?

5. What programmes are the registry staff exposed to on records management to enhance effective management of students' records?

\section{LITERATURE REVIEW}

Records according to Government Record Services (2011) is defined as any recorded information or data in any physical format or media created or received by an organization during its course of official business and kept as evidence of polices, decisions, procedures, functions, activities and transactions. Records management (RM) is the professional practice of managing the records of an organization throughout their life cycle, from the time they are created to their eventual disposal. This includes identifying, classifying, storing, securing, retrieving, tracking and destroying or permanently preserving records (ARAM International, 2013)

\section{Why Is Records Management Important?}

Records management is important because it supports an organization to -

1. make decisions based on evidence;

2. meet operational, legal and regulatory requirements;

3. be open and accountable;

4. enhance operational efficiency and effectiveness; and

5. Maintain organization or collective memory. (Government Record Services, 2011)

Several factors exist that are hindering the efficient management of students' records. Some of these will be discussed briefly discusses in view of how they relate to efficient management of students' records. 
One of the factors affecting efficient management of school records is poor quality and quantity of manpower: Iwhiwhu (2005) stresses the poor quality and quantity of manpower in records management in the school system. He emphasized that manpower is employed without prejudice to qualitative records management most especially in registry.

The world is in a jet system and deserves the people to respond to it accordingly. Many universities are still using the manual format of record keeping which is paper usage (e.g. dropping of copies of papers on the floor in the process of counting it and placing multiple records in bags). All these no doubt must warrant missing of record. We live in paperless age. Much dependence on paper work delays the work and may cost misplacement of students' records. Another issue of great interest to records managers is the impact of the internet and related social media, such as wikis, blogs, forums, and companies such Facebook and Twitter, on traditional records management practices, principles, and concepts, since many of these tools allow rapid creation and dissemination of records and, often, even in anonymous form.

As the world becomes more digital in nature, an ever growing issue for the records management community is the conversion of existing or incoming paper records to electronic form. Such conversions are most often performed with the intent of saving storage costs, storage space, and in hopes of reducing records retrieval time. In the process lots of records are misplaced or mutilated. It is equally very exorbitant for universities and might not be approved soon. Paper records occupy space and takes time to retrieve. Tools such as document scanners, optical character recognition software, and electronic document management systems are used to facilitate such conversions.

According to the State of Montana, Montana Historical Society (2002) and Hounsome (2001), there are many causes of the problem of poor records management practices:

1. Lack of records management policies and procedures. Are they adequate? Are they philosophically consistent across the organization?

2. Lack of qualified staff such as a records manager and archivist. Will the experience and qualifications of the existing staff be suitable for managing a records management programme?

3. Records management costs that are not immediately apparent. Cost may only become significant over a period of time and thus not attract management's attention.

4. Limited resources to implement a system according to requirements (legislation). Is the number of staff and other resource adequate? Is the records retention and disposal schedule in place? Has this been approved by legal services?

Lot of students' have suffered in the hands of many universities owing to missing records in terms of credentials, exam scripts, results and the like. It has added years to their maximum mandate with the institution. This ugly menace is not only deterrent to the student but also to the university as it has led them to litigation in some cases. Chinyemba and Ngulube (2005) admit that proper records management could help universities to manage their information, efficiently fulfill their mandate, protect them from litigation, preserve their corporate memory, and foster accountability and good governance. The information contained in university records need to be managed according to a methodical approach in order to enhance the effectiveness and efficiency of the universities in carrying out their mission. Also, Universities might find themselves in an embarrassing position if requested records are not found as a result of poor records systems where, as Taylor (2000) notes, litigation by aggrieved parties cannot be ruled out. Recently, he said, a former University of Durban-Westville student made a court application demanding to see his examination scripts. This case demonstrates the possibly consequence of not providing information timeously. 
It is on record that university programmes have become extremely complex over the years. It has equally become a recurring decimal that records of students are irretrievable when required especially in Nigerian institutions (Fabunmi, 2004). Nwankwo (2001) as cited by Akor and Udensi (2014) observed also that Nigerian tertiary institutions have an information generation capacity of $76 \%$ and a utilization of $3 \%$. This gap is a huge point to worry about. However, Lundu and Mberve (2004) stated the inability of most educational institutions to put up sound information management policies to guide the generation, processing, storage and retrieval of stored data.

Owing to less attention given to the records management issues by most institutions and giving priority attention to other sectors, the concerns of the registry staff and other record keepers are taken for granted and as such, their training is not considered as a priority. This in turn affects their productivity. Akor and Udensi (2014) noted that records management at university is not receiving the attention it deserves. Society of Human Resource Management (2011) adds that employers may offer job-specific training to provide employees with the appropriate skills to enable them to perform their duties effectively. Nwaomah (2015). The immediate application of skills acquired through such training may boost employee confidence and productivity. Muhenda and Lwanga (n.d) argue that training and development enhance staff's absorption capacity. Muhenda and Lwanga, (n.d), established that employees who are highly trained and whose career development are effectively managed show high levels of commitment, are flexible, multi skilled and capable of making remarkable contribution to the services they render in organizations'. And sadly enough, "some organizations are reluctant to train their staff for fear that upgrading the skills of the workforce, would expose them to competitors" Nwaomah, (2015) added.

Employment of every staff is the responsibility of the university or management. This is aimed at boosting to the universities productivity. However, it has been noticed that some staff are employed based on who brought them and equally placed at the convenience of the one who brought the staff not minding his/her specialization. Registry work or recording management requires professionalism; else, there will be problem. Nwaomah, (2015) citing Lyaruu's (2005) study, revealed the lack of professionalism in records management as the most fundamental problem plaguing registries in most institutions in Tanzania. Similarly, Manyambula (2009) pointed out that one of the factors, which contributed to the poor records management was that administrator staffed most registries with people who had received little or no records management training due to ethnic relationship with leadership. Except these group of people are removed or properly trained records of students must be in jeopardy.

\section{Competencies and skills of record management personnel:}

Above all, record management staff are expected to have specialized characteristics that brings efficiency to their work as clarity of purpose, confident and effective communication skills, both verbally and in writing in the following ways:

a. an ability to communicate and get on well with colleagues at all levels;

b. enthusiasm and is pro-active;

c. a positive "can-do" attitude;

d. completes tasks through to their conclusion;

e. works effectively in a team environment, including in a leadership role;

f. flexibility and an adaptable outlook, including the ability to respond to changing needs and different situations;

g. effective advisory and influencing skills;

h. can deliver effective presentations and training to an audience;

i. shares knowledge and experience; 
j. good analytical skills;

k. marketing and promotional awareness, skills and abilities;

l. personal and professional integrity;

m. ability to develop and maintain a wide network of professional contacts;

n. Keeps up to date with professional developments and actively participates within the professional community (Wieclawska, 2013).

\section{THEORETICAL FRAMEWORK -THE LIFE CYCLE OF RECORD}

Since the late 1930s, "the life cycle theory has been the main conceptual framework for managing records, especially in a paper environment. The life cycle concept was invented by Theodore Schellenberg of the National Archives of the USA in 1934". It falls into three phases, which may be defined as "(1) records creation or receipt (born or adopted); (2) records use and maintenance (that is, they live actively), and (3) records destruction (they die) or transfer to an archival repository (they are reincarnated)" (Ngoepe, 2008). It is relevant to the study in that the record management personnel (registry staff) create records, manage and dispose them at will. And they need to follow the rudiment of record life circle theory.

\section{METHODOLOGY}

Survey research design was used to investigate the factors affecting efficient management of students' records among Babcock university registry staff. The population of the study includes all registry staff in Babcock University which includes both university secretaries (53) and those officially working at the registry office (49) making a total of 102 record management personnel.

A total enumeration technique was used for the study as the researcher intended to work on all the population for a better result. The data collected were analyzed using descriptive statistics. The descriptive statistics was used to analyze the demographic information of the respondents and respondent answers were analyzed using percentages, and tables.

\section{Demographic data of the respondents}

RESULTS AND DISCUSSION OF THE FINDINGS

Percentage point and frequency distribution was used to analyze the demographic data of the respondents as presented and interpreted in the table below: 
Table 1: Demographic information of Registry staff at Babcock University

\begin{tabular}{|l|l|l|l|}
\hline Characteristic & Categories & Frequency & Percentage \\
\hline Gender & Male & 38 & $37 \%$ \\
\hline & Female & 64 & $63 \%$ \\
\hline & Total & 102 & 100 \\
\hline Section & Registry office & 49 & $48 \%$ \\
\hline & Secretaries & 53 & $52 \%$ \\
\hline Age & Total & 102 & 100 \\
\hline & Under 30 & 16 & $16 \%$ \\
\hline & $30-40$ & 50 & $49 \%$ \\
\hline & $41-50$ & 28 & $27 \%$ \\
\hline & $51-60$ & 8 & $8 \%$ \\
\hline $\begin{array}{l}\text { Period of working } \\
\text { experience }\end{array}$ & Total & 102 & 100 \\
\hline & Below 5 years & 30 & $29 \%$ \\
\hline & & & \\
\hline & $5-10 y e a r s$ & 44 & $43 \%$ \\
\hline Qualification & Above 10 years & 28 & $27 \%$ \\
\hline & Total & 102 & 100 \\
\hline & OND/NCE & 18 & $18 \%$ \\
\hline & HND/BSC/BA & 55 & $54 \%$ \\
\hline & MASTER'S DEGREE & 25 & $25 \%$ \\
\hline & PhD & 4 & $4 \%$ \\
\hline & TOTAL & 102 & 100 \\
\hline
\end{tabular}

Results from table 1 shows the demographic status of registry staff at Babcock University indicating female to have $63 \%$ of the total number used for the study. It also shows that the staff are in a higher number within the age bracket 30-40 with $49 \%$. On the experience of the workers, the result shows that $43 \%$ of them have worked within 5-10 years, while in the qualification ranking; workers with first degree are higher in number with 54\%.

Research question one: Is students' records effectively managed in terms of time, efficiency and up datedness in Babcock University registry?

Key: likert scoring order of Strongly Agreed $(S A)=4$, Agree $(A)=3$, Disagree (D) =2, and Strongly Disagree $(\mathrm{SD})=1$.

Table 2

\begin{tabular}{|l|l|l|l|l|l|}
\hline SN & Students' records effective management & $\begin{array}{l}\text { SA (\%) } \\
\mathbf{4}\end{array}$ & $\begin{array}{l}\text { A (\%) } \\
\mathbf{3}\end{array}$ & $\begin{array}{l}\text { D (\%) } \\
\mathbf{2}\end{array}$ & $\begin{array}{l}\text { SD (\%) } \\
\mathbf{1}\end{array}$ \\
\hline 1 & $\begin{array}{l}\text { It takes me a longer time to store or retrieve } \\
\text { students records }\end{array}$ & - & $5(5 \%)$ & $\begin{array}{l}\mathbf{6 0} \\
\mathbf{( 5 9 \% )}\end{array}$ & $\begin{array}{l}37 \\
(36 \%)\end{array}$ \\
\hline 2 & $\begin{array}{l}\text { I am corrected of my work on students records } \\
\text { by my supervisor always }\end{array}$ & $10(10 \%)$ & $\begin{array}{l}33 \\
(31 \%)\end{array}$ & $45(\mathbf{4 5 \% )}$ & $14(14 \%)$ \\
\hline 3 & $\begin{array}{l}\text { Students records in my office are always kept } \\
\text { accurately and retrievable at will }\end{array}$ & $\mathbf{7 8 ( 7 6 \% )}$ & $24(24 \%)$ & - & - \\
\hline
\end{tabular}

The result from table two showed that 59\% of the total respondents disagreed taking longer time to store and retrieve students records. $45 \%$ of then also disagreed of being corrected of their work by their supervisors while on the other hand $76 \%$ strongly agreed the students records at their disposal were accurately kept and retrieved easily. 
Research Question two: How efficient is the personnel in Babcock University registry in managing of students' records?

Table 3- Key: likert scoring order of Strongly Agreed (SA) = 4, Agree (A) = 3, Disagree (D) =2, and Strongly Disagree (SD) $=1$.

\begin{tabular}{|l|l|l|l|l|l|}
\hline SN & $\begin{array}{l}\text { Efficiency of record management } \\
\text { personnel }\end{array}$ & $\begin{array}{l}\text { SA } \\
\mathbf{4}\end{array}$ & $\begin{array}{l}\text { A } \\
\mathbf{3}\end{array}$ & $\begin{array}{l}\text { D } \\
\mathbf{2}\end{array}$ & $\begin{array}{l}\text { SD } \\
\mathbf{1}\end{array}$ \\
\hline 1 & $\begin{array}{l}\text { Accurate capturing of Students' details at first } \\
\text { point of contact }\end{array}$ & $39(38 \%)$ & $61(\mathbf{6 0 \% )}$ & $2(2 \%)$ & - \\
\hline 2 & $\begin{array}{l}\text { Prompt and timely submission of students } \\
\text { data to Stakeholders }\end{array}$ & $68(\mathbf{6 7 \% )}$ & $22(22 \%)$ & $10(10 \%)$ & - \\
\hline 3 & $\begin{array}{l}\text { Maintenance of audit trails for easy tracking } \\
\text { of } \\
\text { students records }\end{array}$ & $80(\mathbf{7 8 \% )}$ & $22(22 \%)$ & - & - \\
\hline 4 & $\begin{array}{l}\text { Confidential handling and processing of } \\
\text { students Records }\end{array}$ & $\mathbf{7 8 ( 7 6 \% )}$ & $24(24 \%)$ & - & - \\
\hline 5 & $\begin{array}{l}\text { Adequate plan exists for disasters control and } \\
\text { management of students records }\end{array}$ & $41(\mathbf{4 0 . 1 \% )})$ & $29(28.4 \%)$ & $30(29.4 \%)$ & $2(2.1 \%)$ \\
\hline
\end{tabular}

Table 3 above showing the efficiency of record management personnel indicated that $60 \%$ of the respondents agreed to capture students' details at first point of contact accurately. It showed prompt and timely submission of students' data, maintenance of audit trails and confidentially handing students' records as $67 \%, 78 \%$ and $76 \%$ respectively; and having adequate plan for disaster control and management of students' records.

Research Question three: What are the problems associated with efficient management of students records in Babcock university registry?

Key: likert scoring order of Strongly Agreed $(S A)=4$, Agree $(A)=3$, Disagree $(D)=2$, and Strongly Disagree $(\mathrm{SD})=1$.

Table 5

\begin{tabular}{|c|c|c|c|c|c|}
\hline SN & $\begin{array}{l}\text { PROBLEMS OF EFFICIENT MANAGEMENT OF } \\
\text { STUDENTS RECORDS }\end{array}$ & $\begin{array}{l}\text { SA } \\
4\end{array}$ & $\begin{array}{l}\text { A } \\
3\end{array}$ & $\begin{array}{l}\mathrm{D} \\
2\end{array}$ & $\begin{array}{l}\text { SD } \\
1\end{array}$ \\
\hline 1 & $\begin{array}{l}\text { Negative attitude in the system e.g laziness, } \\
\text { mediocrity etc. }\end{array}$ & $75(74 \%)$ & $25(25 \%)$ & $2(2 \%)$ & - \\
\hline 2 & $\begin{array}{l}\text { Record management system not well } \\
\text { implemented }\end{array}$ & $66(65 \%)$ & $32(31)$ & $4(4 \%)$ & - \\
\hline 3 & Improper security for records & $54(53 \%)$ & $6(6 \%)$ & $40(39 \%)$ & $2(2 \%)$ \\
\hline 4 & Conventional use of paper for official purposes & $67(66 \%)$ & $35(34 \%)$ & - & - \\
\hline 5 & Lack of professionally trained record managers & $59(58 \%)$ & $43(42 \%)$ & - & - \\
\hline 6 & Inadequate computer terminals & $20(20 \%)$ & $17(17 \%)$ & $43(42 \%)$ & $22(22 \%)$ \\
\hline 7 & Involvement of manual operations & $60(59 \%)$ & $33(32 \%)$ & $6(6 \%)$ & $3(3 \%)$ \\
\hline 8 & Inadequate resources & $34(33 \%)$ & $37(36 \%)$ & $29(28 \%)$ & $2(2 \%)$ \\
\hline 9 & Ineffective means of retrieving records & $30(29 \%)$ & $42(41 \%)$ & $20(20 \%)$ & $10(10 \%)$ \\
\hline 10 & $\begin{array}{l}\text { Lack of records retention and disposition } \\
\text { schedule }\end{array}$ & $54(53 \%)$ & $35(34 \%)$ & $3(3 \%)$ & - \\
\hline 11 & Lack of record management policy & $42(41 \%)$ & $40(39 \%)$ & $13(13 \%)$ & $7(7 \%)$ \\
\hline 12 & Lack of filing procedure manual & $39(38 \%)$ & $16(16 \%)$ & $29(28 \%)$ & $18(18 \%)$ \\
\hline 13 & Acute space problem & $63(62 \%)$ & $36(35 \%)$ & $3(3 \%)$ & - \\
\hline 14 & Transfer and retirements of officers & $28(27 \%)$ & $13(13 \%)$ & $37(36 \%)$ & $24(24 \%)$ \\
\hline
\end{tabular}


Table 5 presented the responses of record management staff at Babcock University with regard to the associated problems of record management in the institution. The table showed that the items considered very high in the respondents' level of acceptance which included negative attitude in the system (74\%), not well-implemented management system (65\%), improper security for records (53\%), and conventional use of paper for official purposes (66\%). Other problems which were accepted were lack of professionally trained managers (58\%), manual operation (59\%), inadequate resources (36\%), ineffective means of retrieving records (41\%), lack of records retention and disposition schedule (53\%), lack of policy (41\%), lack of filing manual and acute space problem had percentage rating between $38 \%$ and $62 \%$ respectively. However, respondents rejected involvement in inadequate computer terminals (42\%) and in transfer and retirement of staff with (36\%). The result therefore shows that these factors affect record management in Babcock University.

Research Question four: What ways/options can be used to improve management of students' records in Babcock University Registry?

Key: likert scoring order of Strongly Agreed $(S A)=4$, Agree $(A)=3$, Disagree $(D)=2$, and Strongly Disagree (SD) $=1$.

Table 6

\begin{tabular}{|l|l|l|l|l|l|}
\hline SN & $\begin{array}{l}\text { OPTIONS TO IMPROVE MANAGEMENT OF } \\
\text { STUDENTS RECORDS }\end{array}$ & $\begin{array}{l}\text { SA } \\
\mathbf{4}\end{array}$ & $\begin{array}{l}\text { A } \\
\mathbf{3}\end{array}$ & $\begin{array}{l}\text { D } \\
\mathbf{2}\end{array}$ & $\begin{array}{l}\text { SD } \\
\mathbf{1}\end{array}$ \\
\hline 1 & Periodical check to ensure proper management & $87(\mathbf{8 5 \% )}$ & $15(15 \%)$ & - & - \\
\hline 2 & Need for professional training of staff & $90(\mathbf{8 8 \%})$ & $12(12 \%)$ & - & - \\
\hline 3 & Maintenance of confidentiality & $95(\mathbf{9 3 \%})$ & $7(7 \%)$ & - & - \\
\hline 4 & Availability of Policy enlightenment & $84(\mathbf{8 2 \%})$ & $18(18 \%)$ & - & - \\
\hline 5 & Computerization of all universities' records & $98(\mathbf{9 6 \%})$ & $4(4 \%)$ & - & - \\
\hline 6 & Induction/orientation for new staff & $88(\mathbf{8 6 \%})$ & $14(14)$ & - & - \\
\hline 7 & $\begin{array}{l}\text { Record retention policy/record manual are } \\
\text { encouraged }\end{array}$ & $77(\mathbf{7 5 \%})$ & $23(23 \%)$ & $2(2 \%)$ & - \\
\hline 8 & Full implementation of internet services & $96(\mathbf{9 4 \% )}$ & $6(6 \%)$ & - & - \\
\hline 9 & Adequate provision of funds & $100(\mathbf{9 8 \%})$ & $2(2 \%)$ & - & - \\
\hline 10 & Compliance with international standards & $69(\mathbf{6 8 \%})$ & $21(21 \%)$ & $12(12 \%)$ & - \\
\hline
\end{tabular}

Table 6 showed a total affirmation on the options to improve management of students' records by the respondents from the 10 items with a range of $68 \%$ and $98 \%$. These include periodical check to ensure proper management (85\%), need for professional training of staff (88\%). Confidentiality (93\%), policy enlightenment (82\%), computerization of all records (96\%), induction for new staff (86\%), record retention manual (75\%), full implementation of internet services (94\%) and adequate provision of fund (98\%) and the 10th item compliance with international standards (68\%).

Research Question five: what programmes are the staff exposed to for records management in the University to enhance effective management of students' records? 
Table 7: Key: pls tick as appropriate below

\begin{tabular}{|l|l|l|l|}
\hline SN & $\begin{array}{l}\text { Programs to enhance effective } \\
\text { management of students' records }\end{array}$ & ATTENDED & NOT ATTENDED \\
\hline 1 & $\begin{array}{l}\text { Seminar(s) on students record } \\
\text { management }\end{array}$ & $45(44 \%)$ & $57(\mathbf{5 6 \%})$ \\
\hline 2 & $\begin{array}{l}\text { Workshop (s) on students record } \\
\text { management }\end{array}$ & $39(38 \%)$ & $63(\mathbf{6 2 \% )})$ \\
\hline 3 & Symposia on student records management & $28(27 \%)$ & $74(\mathbf{7 3 \%})$ \\
\hline 4 & $\begin{array}{l}\text { Orientation on students records } \\
\text { management }\end{array}$ & $76(\mathbf{7 5 \% )}$ & $26(25 \%)$ \\
\hline
\end{tabular}

Table 7 looked at Programs that can enhance effective management of students' records as seminars, workshops, symposia and orientation all based on students records management. The result showed that the respondents had not attended seminars related to records management with (56\%), workshops $(62 \%)$ and $73 \%$ on symposia while they indicated attendance to orientation (75\%).

\section{DISCUSSION OF FINDINGS}

The result of research question one which seeks to know if students' records are effectively managed in terms of time, efficiency and up datedness in Babcock University registry showed that record managers here manage their students records effectively in terms of time, efficiency and up datedness. The result agrees to the findings of Chinyemba and Ngulube (2005) who admitted that proper records management could help universities to manage their information, efficiently fulfill their mandate, protect them from litigation, preserve their corporate memory, and foster accountability and good governance.

Result from research question two which needed to know how efficient the staff in Babcock University registry are in managing of students' records strongly indicated that accurate capturing of students details at first contact, prompt and timely submission of student data, maintenance of audit trials for easy tracking of students records, confidentiality in handling and processing of students records and adequate plan for unforeseen disaster were taken cognizance of. This showed that tactically concerned with students records. This result therefore has similar voice to the work of Uwaifo (2004); Akporhonor and Iwhiwhu (2007) who stated that record management must be guided by some level of confidentiality, proper maintenance, security, and preservation of the content and context etc.

The result of research question three certifies that there are negative factors associated with efficient management of students' records in Babcock University as: negative attitude of staff, badly implemented record management system, insecurity of records, use of paper convention, lack of training, manual operation, inadequate computer terminal and resources to ineffective retrieving, retention and disposition schedule, as well as lack of policy and filing procedure manual. These factors agree with the opinions of Egwunyenga $(2002,2009)$, and Iwhiwhu (2005) who pointed out at different times in their respective studies that records kept by Nigerian universities, their acquisition policy, methods of preserving and disseminating them are faulty. Through this finding no doubt, one could explain what makes it is very difficult to gather information from many universities archives (registry) especially students' records such as transcripts, sometimes examinations scores which may be declared missing and many other general administrative documents. Often times, students records are mutilated .this situation most often causes great disappointment to the corporate image of the institution.

Research question four dealt with options to improve management of students' records. In other to ensure efficient management of students' records, the study came up with these useful 
measures including periodical checking of records, professional training, and full computerization of the system, policy enlightenment, provision of records manual, introduction of internet services, and adequate provision of funds, security and storage facilities as generally acknowledged by the respondents. These confirm the approaches put forward by Ogundele (2001) who believes that employee training and staff development are continuous life processes and are imperative because they add quality to management processes. More so, the findings agreed with Fadokun (2004) and Tower (2004) who share the idea of adequate security, storage facilities and funds as necessities for good record management. Therefore, in the researcher's opinion, if these options discussed are welladopted, the problems so far identified as factors affecting efficient management of students records will be drastically reduced if not totally eliminated.

Research question five which tried to expose programmes the staff undergo to enhance efficient management of students records discovered that seminars/workshops/symposia in the field of records management are poorly attended by the staff. This has a backing of Akor and Udensi (2014) who noted that records management at university is not receiving the attention it deserves. The whole idea is offering training and development to the personnel for optimal productivity. The little awareness to them is the orientation that is giving to them by the university which is not the best for the institution. The personnel should be allowed to attend compulsory conferences, seminars and symposia and workshops annually to enhance their professionalism. Accordingly, this situation is in line with the competencies of record management personnel stating that they need to keep up to date with professional developments and actively participating within the professional community and also supported by (Nwaomah 2015; Society of Human Resource Management, 2011; Muhenda and Lwanga (n.d) ; Marrow (2001), in Muhenda and Lwanga, (n.d)) who said that employers may offer job-specific training to provide employees with the appropriate skills to enable them to perform their duties effectively; The immediate application of skills acquired through such training may boost employee confidence and productivity; that training and development enhance staff's absorption capacity and they established that employees who are highly trained and whose career development are effectively managed show high levels of commitment, flexible, multi skilled and capable of making remarkable contribution to the services they render in organizations'.

\section{CONCLUSION}

This study indeed exposes the fact that though the personnel in registry department attempts to manage their student record, they still lack educational prerequisite to mind students records and no wonder cogent factors are noticeable in handling the students records. Also, the study indicated that only a microcosm of the personnel attends professional training in records management and these calls for urgent attention. Acknowledging these factors that affect efficient management of students' records among record management personnel here means that university management should have a second look at it by considering the recommendations thereof for solutions.

\section{RECOMMENDATION}

In other to avoid further challenges that may bring about negative impact on the management of students' records in Babcock University registry and any other university where student records are kept, the following recommendations are suggested:

1. Personnel handling students records must be professionals in record management or skilled in related fields;

2. There should be regular in-house training of the registry personnel to fill the areas of need that will actuate efficient records management practices in the university; 
3. Students' records should be digitized to avoid manual record keeping and less paper system in any aspect of students' record keeping;

4. The University management should begin to treat records as an asset;

5. Legal and regulatory compliance in record management must be adhered to.

\section{Reference}

Akor, P. U., \& Udensi, J. (2014). An assessment of Record management System in Establishment Division of Two Universities in Nigeria. International letters of social and humanistic sciences ISSN 2300-2697, vol. 13, pp 97-109

Akporhonor, B. A. \& Iwhiwhu, E. B. (2007). The management of Staff records at Delta State University Library, Abraka, Nigeria. Library Philosophy and Practice (e-journal)

Anho, J. E. (2006). Identification and analysis of problem in the administration of students' personal support services in Nigerian Universities. Unpublished Ph.D Thesis, Delta State University, Abraka.

Atulomah, B.C. (2011). Perceived records management practice and decision making Among university administrators in Nigeria. Library Philosophy and Practice.

[Accessed 22th February 2013] Available from World Wide Web:http://unilib.uni.edu/lpp/

ARMA International. (2013). "Glossary of Records and Information Management Terms, 3rd Edition". ARMA International. Retrieved September 2013.

Blink (2015). Records management: Your role and responsibilities. (last updated November 30, 2015)

Chinyemba, A. \& Ngulube, P. (2005). Managing records at higher education institutions: a case study of the University of KwaZulu-Natal, Pietermaritzburg Campus. South African Journal of Information Management. Vol. 7(1) March 2005

Egwunyenga, E. J (2002). Essentials of School Administration. Benin City: Justice Jeco Publishers.

Egwunyenga, E. J (2009). Record Keeping in Universities: Associated Problems and Management Options in South West Geo-Political Zone of Nigeria. Int J Edu Sci, 1(2): 109-113

Fabunmi, M. (2004). Perspective in Educational planning. uOdun Prints and Pack; Agbowo, Ibadan Nigeria.

Fadokun, J. B (2004). Deregulation and Professional Development in School Personnel. Lecture presented at the National Institute for Educational Planning and Administration .Ondo. August 16-18 2004.

Government Records Service (2011). Good Records Management Practices

Ifedili, C. J. \& Agbaire, J. T. (2011). Management of educational records in Nigeria universities records in Nigeria universities for better results. Review of European studies, 3 (2), 52 - 57.

Iwhiwhu, B. E. (2005). Management of records in Nigeria universities: problems and prospects. Emerald journal $23(3), 345-355$.

Jisc InfoNet (2007). Hei Records management. Guidaince on managing students' records

Lundu, M. C. \& Mbewe, G. (2004). Factors retraining the formulation and Implementation of National Information Policy (NIP) Process.

Lyaruu, T. (2005). Personnel records management in the public sector and its impact on the payment of pension: case study of selected ministries and government agencies. MA Thesis. Dar-es-salaam: University of Dar es Salaam.

Manyambula, M. (2009). Public service reform, accountability and records management: a case study of Tanzania. ESARBICA Journal, 28, 20-35.

Mnjama, N. M. (2002). Managing university records. ESARBICA JOURNAL: journal of the eastern and southern African regional branch of the international council on Archives 21: 32-40

Muhenda, M. B., \& Lwanga, E. K. (n.d). Managing Records in Higher Education Institutions in Uganda: Can Human Resource Policies Salvage the Situation? [Accessed July 25th 2017] Available from World Wide Web:

http://www.wbiconpro.com/406-Mary.pdf

Ngoepe, M. S. (2008). An Exploration Of Records Management Trends In The South African Public Sector: A Case Study Of The Department Of Provincial And Local Government. A dissertation submitted to University of South Africa. 
Ngulube, P. (2004). Fostering accountability and justice: opportunities for record managers in changing societies. ESARBICA JOURNAL: journal of the Eastern and Southern African Regional branch of the international council on Archives 23:23-32

Nwankwo, J. I. (2001). Fundamental of Management information systems. Spectrum books Ltd., Ibadan.

Nwaomah, A. E. (2015). Political Factors' Influence On Students' Records Management Effectiveness In The Nigerian University System. European Journal of Research and Reflection in Management Sciences. Vol. 3 No. 2 ISSN 2056-5992.

Ogundele A. (2001). Staff Development for Improvement School Management. In: NA Nwagwu, ET Ehiemetalor, MA Ogunu, M Nwadiani (Eds.): Current Issues in Educational Management in Nigeria. Benin City: NAEAP.

Olagboye, A. A. (2004). Introduction to Educational management in Nigeria. Ibadan: daily graphics Nigeria.EA

Omoha, F. D. (2013). Management Of School Records In Secondary Schools In Otukpo Education Zone. Thesis Submitted To The Department Of Educational Foundations, University Of Nigeria, Nsukka.

Oyebo, Y. (2016). Innovations and Tools for Records Management in an Electronic Era. A paper presentation at the NLA LITT Workshop held at Yaba Technology, Lagos 17-21 October, 2016

Popoola, S. O. (2000). A cost model approach to records management system in the civil service of Oyo State, Nigeria. Unpublished Ph.d Thesis submitted to the department of Library, Archival and information studies, university of Ibadan, Ibadan

Read, J. \& Ginn, M. L. (2011). Records Management. 9th edition, www.cengage.com/officetech/read

Research Clue, (2014). Factors affecting the efficient management of students' academic records info@researchclue.com

Society for Human Resource Management (2011). Employee job satisfaction and engagement. Retrieved from http://www.shrm.org/research/surveyfindings/articles/documents/11 0618\%20job_satisfaction_fnl.pdf. on July $18,2013$.

Taylor M (2000). Records management at tertiary institutions in the SCECSAL region at the dawn of the new millennium. In: Chisenga J, Chitambo A, Onyango F (eds). Information 2000: a vision for the SCECSAL region. Windhoek: Namibian Information Workers Association: 239-245

Tower Software (2004). Best Practice in Corporate Record Keeping and Archiving: Head Office Camberra Act.www.towersoft.com.au. (Retrieved December 15, 2008)

Uwaifo, S. O. (2004). Management use of records in Delta State University, Abraka, Nigeria

Wieclawska, A. (2013). Record Management Competency Framework. National Records of Scotland (NRS) 